\title{
Two spider species of the genus Anepsion (Araneae: Araneidae) from Thailand, with a note on the synonymy of Anepsion japonicum (Bösenberg \& Strand 1906)
}

\author{
Wimolwan Chotwong ${ }^{1}$, Akio Tanikawa ${ }^{2} *$, Yusuke Ikeda ${ }^{\dagger} \&$ Tadashi Miyashita $^{2}$ \\ ${ }^{\prime}$ Entomology and Zoology Group, Plant Protection Research and Development Office, Department of Agriculture, \\ Chatuchak, Bangkok 10900, Thailand \\ E-mail: wimolwanc@hotmail.com \\ ${ }^{2}$ Laboratory of Biodiversity Science, School of Agriculture and Life Sciences, The University of Tokyo, \\ 1-1-1, Yayoi, Bunkyo-ku, Tokyo, 113-8657 Japan \\ Deceased \\ *Corresponding author.E-mail:dp7a-tnkw@j.asahi-net.or.jp
}

\begin{abstract}
Male spider specimens collected in Thailand were identified as males of Anepsion japonicum Yaginuma 1962. There was no conclusive evidence that female specimens collected at the same time belong to the same species, because the female of the species has not been described. We compared morphological data and mt-COI sequencing data for these female specimens with those of males and concluded that the female specimens belonged to the same species as the males. However, comparison of morphological data for the females and the holotype of Paraplectana japonica Bösenberg \& Strand 1906 revealed that Anepsion japonicum Yaginuma 1962 is a junior synonym of $P$. japonica. Furthermore, after examining the taxonomic features of the holotype of $P$. japonica, it became clear that this species should be placed in the genus Anepsion. Therefore, the specific name was changed to Anepsion japonicum (Bosenberg \& Strand 1906). Consequently, this work permits recording of two new spider species from Thailand: Anepsion depressum (Thorell 1877) and Anepsion japonicum (Bösenberg \& Strand 1906).
\end{abstract}

Key words - Anepsion depressum, Anepsion japonicum, Paraplectana japonica, new records, new synonymy, Thailand, COI, DNA

\section{Introduction}

The spider genus Anepsion Strand 1929 comprises 17 species described from Southeast and East Asia (Platnick 2012), but this genus has not been recorded in Thailand. After examining spider specimens collected from several localities in Thailand, we recognized several species of the genus. Some of the females seemed to be Anepsion japonicum Yaginuma 1962, but we could not confidently identify them because this species has been described on the basis of the male holotype only and the female has not been reported.

The morphological features of the female A. japonicum are unknown. Therefore, we tried to identify the female specimens using mt-COI sequencing data, in accordance with a previous study (Robinson et al. 2009), in which intraand interspecific sequence divergences of the mt-COI barcoding region from 19 genera, 361 morphospecies and 1801 individual spiders were examined to assess whether this barcoding region is appropriate for identification of spider species. Robinson et al. found a mean intraspecific divergence of $2.15 \%$ (average maximum $3.16 \%$ ) and a mean divergence between the nearest interspecific relative of $6.77 \%$. The study also showed that $66 \%$ of morphospecies formed monophyletic sequence clusters and that the majority $(92.5 \%)$ of the species had a "barcode gap" (for terminology, see Robinson et al. 2009). High intraspecific (Bayer \& Schönhofer 2013) and low interspecific (Lattimore et al. 2011) sequence divergence have been found, but COI sequence data have been used in taxonomy for species identification of a juvenile specimen (Bayer \& Schönhofer 2013), determining the opposite sex in a particular species (Tanikawa 2011), synonymizing two spider species (Vink et al. 2011), and disproving synonymies (Correa-Ramirez et al. 2010). Therefore, DNA barcoding seems to be a useful tool for taxonomic studies.

We noticed that the female specimens from Thailand that were considered to be $A$. japonicum had a similar abdominal coloration to the original figure of Paraplectana japonica Bösenberg \& Strand 1906, which was described on the basis of only the female holotype from Japan and has not been subsequently recorded. Therefore, we examined the 
holotype of $P$. japonica carefully to verify whether these two species are distinguishable. The results of the study newly add the Anepsion species to the spider fauna of Thailand. The taxonomic identities of $A$. japonicum and $P$. japonica are clarified in accordance with our identification of the female specimens in question.

\section{Materials and method}

The specimens used for the morphological study were preserved in $75 \%$ ethanol at room temperature. The morphological features were examined under stereoscopic microscopes (M3Z, Wild Heerbrugg AG, Heerbrugg, Switzerland; and SZH, Olympus Corp., Tokyo, Japan), photographs were taken with EOS D60 with a MP-E65MM macro lens and a MT-24EX macro twin flash (Canon Inc., Tokyo, Japan). Details of the examined specimens are shown in the taxonomy section.

Specimens used for molecular analysis (see Appendix) were preserved in $75 \%$ or $99.5 \%$ ethanol at room temperature or $4{ }^{\circ} \mathrm{C}$. Genomic DNA was extracted from the whole cephalothorax using a FavorPrep Tissue Genomic DNA Extraction Mini Kit (Favorgen Biotech Corp, Ping-Tung, Taiwan). mt-COI was amplified using the primer set LCO1498: 5'-GGT CAA CAA ATC ATA AAG ATA TTG G-3' and HCO2198: 5'-TAA ACT TCA GGG TGA CCA AAA AAT CA-3' (Folmer et al. 1994). The reactants were initially denatured for $2 \mathrm{~min}$ at $94^{\circ} \mathrm{C}$, followed by 40 cycles of $15 \mathrm{~s}$ at $94^{\circ} \mathrm{C}, 20 \mathrm{~s}$ at $47^{\circ} \mathrm{C}$, and $30 \mathrm{~s}$ at $72^{\circ} \mathrm{C}$. PCR products were purified using the ExoSAP-IT (GE Healthcare Bio-Sciences, Little Chalfont, England). Purified PCR products were sequenced using a BigDye terminator cycle sequencing kit (ver. 3.1, Applied Biosystems, Foster City, CA) and analyzed on an ABI 3130xl automated DNA sequencer (Applied Biosystems). Chromatograms were checked by eye using MEGA version 5.05 (Tamura et al. 2011). Obtained sequences were aligned using MUSCLE (Edgar 2004) in MEGA. The phylogenetic tree was constructed by the neighbor-joining (NJ) method using MEGA.

The voucher specimens used in this study are deposited at the Entomology and Zoology Section, Plant Protection Research and Development Office, Department of Agriculture, Bangkok, and at the Princess Maha Chakri Sirindhorn Natural History Museum, Hatyai, Thailand. Nucleotide sequence data are available in the DDBJ/EMBL/GenBank databases. All measurements are given in $\mathrm{mm}$.

\section{Results}

Our morphological examination led to recognition of two species of Anepsion among the specimens (Figs. 2-7). We identified one as Anepsion depressum (Thorell 1877) (Figs. 2-4) and the male specimens that did not belong to $A$. depressum as A. japonicum Yaginuma 1962 (Fig. 7), based on comparison with previous morphological descriptions (for references, see synonymy in the Taxonomy section below). The male holotype of $A$. japonicum has lost its

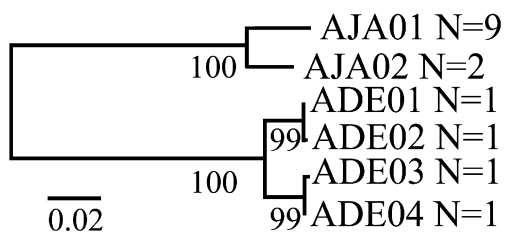

Fig. 1. Unrooted bootstrap consensus tree obtained by the neighbor-joining method for the haplotypes detected. Scores at each node are bootstrap values (1000 replicates). Scale bar shows substitutions per site.

coloration and markings, and its palpal organ has been slightly deformed. However, confirmation of the assignment was based on the original figure (Yaginuma 1962, fig. 8) illustrating this specimen, which showed the shapes of each sclerite of the male palpal organ, especially the swollen conductor and elongated median apophysis (Fig. 13). The female specimens had a similar general appearance to the identified male specimens (Figs. 5-7).

We obtained $609 \mathrm{bp}$ of mt-COI partial sequences from the specimens for molecular analysis. Haplotype names and accession numbers are shown in the Appendix. Two haplotypes were detected in three males of $A$. japonicum and in unidentified females (AJA01 and AJA02 in Fig. 1 and Appendix). A total of 11 specimens were analyzed: 4 females, 3 males and 2 juveniles with the same haplotype (AJA01); and 2 females with the other haplotype (AJA02). The uncorrected p-distance (number of base differences per site) between AJA01 and AJA02 was 0.036. In the obtained unrooted NJ tree (Fig. 1), specimens identified as $A$. depressum (haplotype ADE01-04) and males of $A$. japonicum and unidentified females (haplotypes: AJA01 and AJA02) formed respective clades.

The holotype of Paraplectana japonica Bösenberg \& Strand 1906 is a subadult, but the shape of its epigyne could be observed under the exoskeleton. Thus, we were able to confirm that the scape of the holotype is slim, and our female specimens also had a slim scape (Fig. 11). The black coloration on the dorsum of the abdomen has somewhat faded, but still remained as in the original figure (Fig. 8; Bösenberg \& Strand 1906, fig. 424A). Our female specimens had the same marking (Fig. 5). The holotype specimen has a swollen cephalic region, round shaped and flattened abdomen, as in the original figure (Fig. 8; Bösenberg \& Strand 1906, fig. 424A), and these features were also present in our female specimens (Fig. 5).

\section{Taxonomic revision of Anepsion japonicum and Paraplectana japonica}

We identified the female specimens as A. japonicum because the coloration and markings were in exact agreement with those of the male specimens of $A$. japonicum, and their mt-COI sequencing data were the same as or similar to those of the males. Thus, both the morphological data and mt-COI sequencing data showed that these male and female specimens belong to the same species. The female 


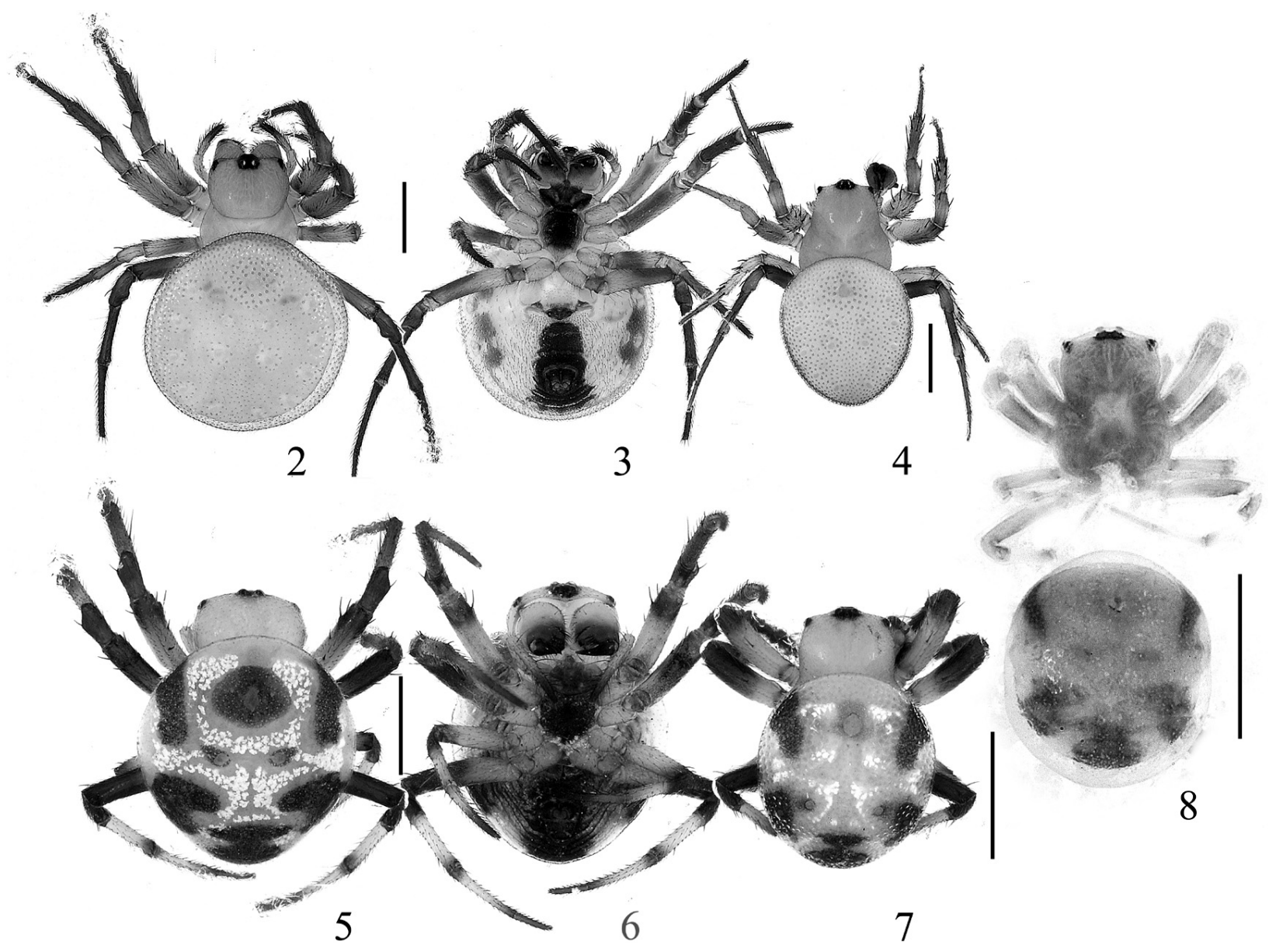

Figs. 2-8. Habitus. 2-4, Anepsion depressum (Thorell 1877) from Nakhon Ratchasima Province; 5-7, Anepsion japonicum (Bösenberg \& Strand 1906) n. comb. from Nakhon Ratchasima Province; 8, Paraplectana japonica Bösenberg \& Strand 1906, holotype. 2, 5, 8, female, dosal view; 3, 6, same, ventral view; 4, 7, male, dorsal view. Scales $=1 \mathrm{~mm}$.

specimens of A. japonicum have the same coloration and markings, and the same slim epiginal scape as the holotype of $P$. japonica. Therefore, we concluded that $A$. japonicum is a junior synonym of $P$. japonica. In addition, $P$. japonica Bösenberg \& Strand 1906 should be placed under the genus Anepsion because they have the conspicuous features of the genus: that is, a swollen cephalic region and a flattened abdomen. The gender of the generic name Paraplectana is feminine while Anepsion is neutral. Therefore, the specific name japonica should be changed to japonicum. Moreover the authors of this specific name should be enclosed in parentheses because this name is combined with a generic name other than the original one. Thus, the species name, $P$. japonica, should be cited as Anepsion japonicum (Bösenberg \& Strand 1906) n. comb.

\section{Taxonomy}

\section{Anepsion depressum (Thorell 1877)}

(Figs. 2-4, 9-11)

Paraplectana depressa Thorell 1877, p. 353. [female holotype from Fujian preserved in Museo Civico Storia Naturella, Genova, not examined] Anepsia depressa: Simon 1895, p. 868, fig. 930.

Anepsion depressum: Chrysanthus 1961, p. 466, figs. 13-17; Chrysanthus 1969, p. 32, figs. 3-5; Zhu et al 1994, p. 26, figs. $1 \mathrm{~A}^{-}$C; Yin et al 1997, p. 116, figs. 41a-c; Song, Zhu \& Chen 1999 , p. 236 , figs. $133 \mathrm{O}^{-} \mathrm{P}, 146 \mathrm{C}$.

Specimens examined. 1우1 $\delta^{7}, 9-\mathrm{XI}-2011,1$ 우, 23-XI2012, Sakaerat Environmental Research Station, Wang Nam Khieo District, Nakhon Ratchasima Province, W. Chotwong leg. 1 우, Phlio waterfall, Laem Sing District, Chanthaburi Province, 23-V-2012, W. Chotwong leg. 1우, 2-VIII-2012, 1 우1ð , 3-VIII-2012, 1ð, 19-IX-2012, 2우, 28-IX-2012, Khuan Khao Wang Forest Park, Tumbon Chalung, Amphoe Hat Yai, Songkhla Province. B. Petcharad leg.

Diagnosis. This species can be easily distinguished from Anepsion japoncum by having yellowish abdomen without any markings.

Description. Coloration and markings in alcohol. Female and male (Figs. 2-4): carapace yellow, sternum, labium and endite dark brown; dorsum of abdomen yellow; 

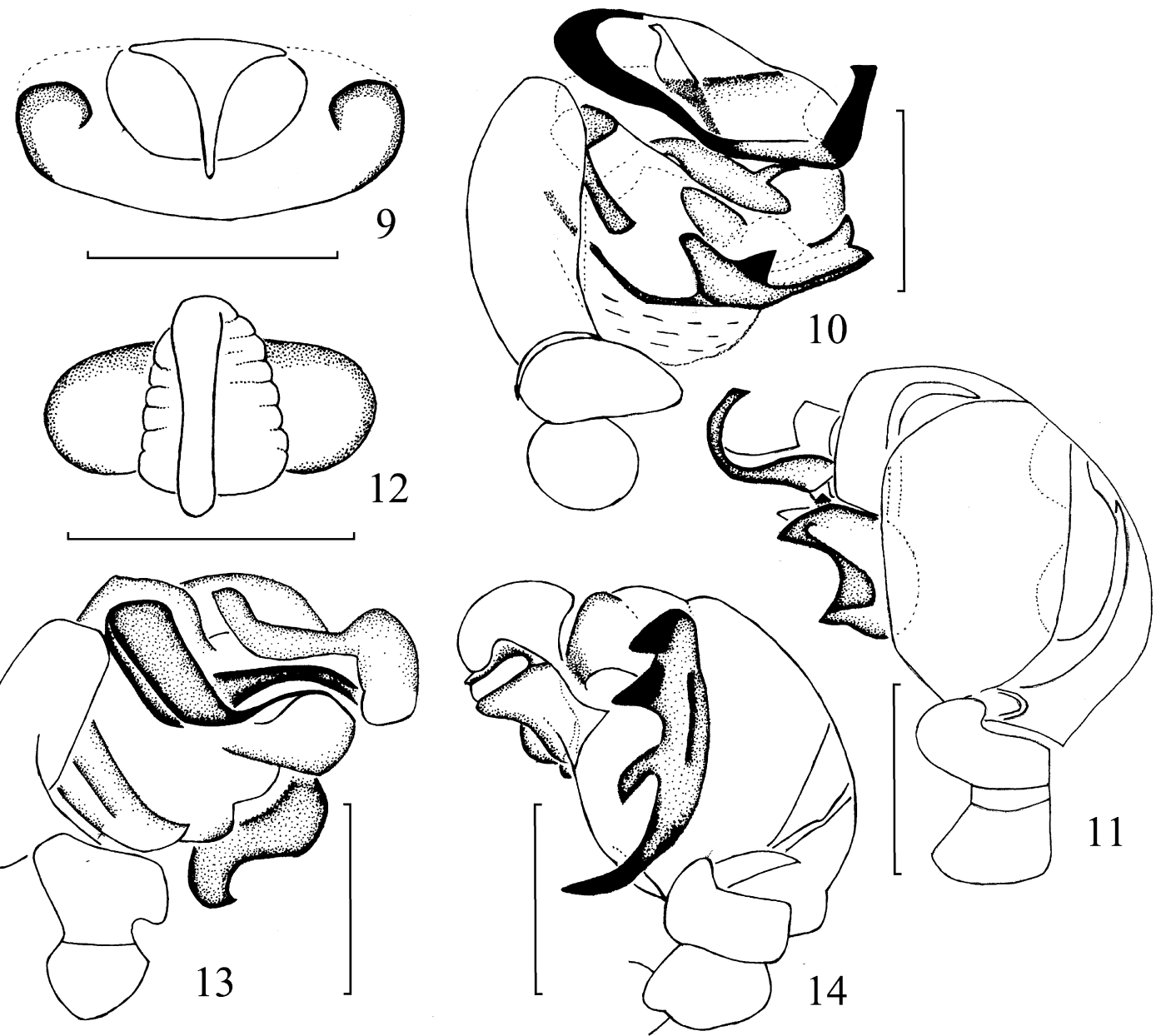

Figs. 9-14. Genital organ. 9-11, Anepsion depressum (Thorell 1877) from Nakhon Ratchasima Province; 12-14, Anepsion japonicum (Bösenberg \& Strand 1906) n. comb. from Nakhon Ratchasima Province. 9, 12, epigyne; 10, 13, male left palp, prolateral view; 11, 14, same, retrolateral view. Scales $=0.25 \mathrm{~mm}$.

venter with broad dark brown blot extend from epigastric furrow until the posterior end, surrounding dark brown spinnerets, and laterally with black color pattern.

Measurement. Based on 1우워 from Nakhon Ratchasima province, Thailand. Measurements in parentheses indicate the range among specimens examined. Body o 4.33 (3.074.33) / ठ 3.30 long. Carapace 우 $1.80(1.47-1.87)$ / 万 2.3 long; 우 $1.53(0.67-1.53) /$ 万 2.00 wide. Length of legs [우 / $\delta^{\top}$ : tarsus + metatarsus + tibia + patella + femur $=$ total]: ?, $0.35+0.90+0.85+0.40+1.10=3.62 / 0.23$ $+0.6+0.77+0.47+0.83=2.90 ;$ II, $0.15+0.60+$ $0.70+0.40+1.20=3.05 / 0.23+0.5+0.47+0.27$ $+0.87=2.34$; III, $0.40+0.55+0.50+0.35+0.85$ $=2.65 / 0.23+0.47+0.43+0.33+0.8=2.26$; IV, $0.45+1.20+0.95+0.60+1.40=4.60 / 0.33+0.83$ $+0.70+0.33+1.1=3.29$. Abdomen 우 $3.13(2.33-$ $3.53) /$ 万 2.30 long, ㅇ $3.20(2.40-3.47) /$ \ 2.00 wide.

Carapace longer than wide [length / width 우 1.18 (1.182.19) / 万 1.22], head region swollen. Median ocular area almost as long as wide [length / width ㅇ $0.93\left(0.86^{-0.93) / ~}\right.$ o 0.92]; almost as wide in front as behind [anterior width / posterior width ㅇ $0.93(0.93-1.00) / \delta 1.00]$. Fang furrow of chelicerae with 우 $3\left(3^{-5}\right) /$ o 4 promarginal teeth and 우 5 / क 4 retromarginal teeth. Labium wider than long [length / width o $0.71\left(0.43^{-0.71)} / \delta^{7} 0.50\right.$. Sternum longer than wide [length / width 우 $1.21(1.14-1.21) /$ o 1.54 . Length of leg I / length of carapace ㅇ $2.00\left(1.90^{-} 2.17\right)$ / o 2.07. Male palp (Figs. 10-11): embolus long and apically bent, median apophysis with two sharp points in rertolateral view (Fig. 11). Abdomen flattened, almost as long as wide [length/width 우 $0.98(0.97-1.02) /$ o 1.15$]$, scattered with small brownish pits, and with large sigilla. Female genitalia (Fig. 9): epigyne with invert triangle scale.

Distribution. Thailand, Burma, Sulawesi, and China.

Anepsion japonicum (Bösenberg \& Strand 1906) n. comb. [Japanese name: Yamato-janome-gumo]

(Figs. 5-7, 12-14)

Paraplectana japonica Bösenberg \& Strand 1906, p. 242, pl. 15, fig. 424. [subadult female holotype from Saga, Japan, preserved in Senckenberg Museum, no. 4179, examined] Anepsium japonicum Yaginuma 1962. p. 134, figs. 6-8. [male holotype from Kagoshima Pref., Japan, preserved in Otemon 
Gakuin University, examined] NEW SYNONYMY

Anepsion japonicum: Yaginuma 1986, p. 123, fig. 65.1; Yin et al 1997, p. 117, figs. 42a-c; Song, Zhu \& Chen 1999, p. 236, fig. 134B-C, 146D; Tanikawa, 2007, p. 55, fig. 485; Tanikawa 2009, p. 433, fig. 67. NEW SYNONYMY

Specimens examined. 1 우 $10^{\top}$, Sakaerat Environmental Research Station, Wang Nam Khieo District, Nakhon Ratchasima Province, 9-XI-2011, W. Chotwong leg. 6우1万, Tapon Khlung, Chanthaburi Province, 24-XII-2012, W. Chotwong leg. 6우3적, Petchaburi Province, 19-XI-2012, W. Chotwong leg. 1아 juv, Nayong District, Trang Province, 11-V-2012, V. Saksongmeung leg. 1juv., Manang District, Satun Province, 12-IX-2011, B. Petcharad leg.

Diagnosis. This species can be easily distinguished from A. depressum by having a black marking on the dorsum of abdomen.

Description. Coloration and markings in alcohol. Female and male (Figs. 5-7): carapace pale brown, without marking, sternum, labium and endite dark brown. Dorsum of abdomen white with blackish markings.

Measurement. Based on 1우 from Petchaburi Province and $10^{\lambda}$ from Chantaburi Province. Measurements in parentheses indicate the range among specimens examined. Body 우 $2.64(2.08-2.70)$ / 주 $2.03(1.85-2.03)$ long. Carapace 우

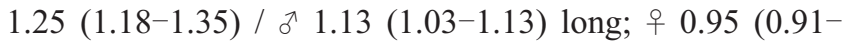
$1.03)$ / ð $0.90(0.83-0.90)$ wide. Length of legs [우 / ð⿱: tarsus + metatarsus + tibia + patella + femur $=$ total $]:$ I, $0.35+0.63+0.50+0.43+0.83=2.74 / 0.30+0.53$ $+0.55+0.38+0.73=2.49 ;$ II, $0.30+0.55+0.46+$ $0.40+0.80=2.51 / 0.28+0.45+0.43+0.38+0.73$ $=2.27$; III, $0.28+0.35+0.30+0.28+0.58=1.79$ $/ 0.25+0.30+0.30+0.28+0.55=1.68 ; \mathrm{IV}, 0.33+$ $0.65+0.50+0.38+0.75=2.61 / 0.28+0.51+0.48$ $+0.33+0.75=2.35$. Abdomen 우 $1.95(1.53-1.95) /$ Љ $1.43(1.33-1.85)$ long, 우 $1.88(1.43-2.13)$ / ๙ $1.26\left(1.20^{-}\right.$ 1.28) wide.

Carapace longer than wide [length / width 우 1.32 (1.241.32) / $₫ 1.25$ (1.21-1.25)], head region swollen. Median ocular area almost as long as wide [length / width 우 1.00 (0.89-1.00) / $1.00(0.94-1.00)]$; wider behind than in front [anterior width / posterior width 우 $0.89(0.83-0.94)$ / § 0.94 (0.87-0.94)]. Fang furrow of chelicerae with 우 4 (4-5) / ऽ 4 (3-5) promarginal teeth and 우 $3(3-6) /$ ๙ 4 (3-4) retromarginal teeth. Labium wider than long [length / width 우 $0.41(0.41-0.55) / \curvearrowright 0.57(0.47-0.57)$. Sternum slightly longer than wide or as long as wide [length / width 우 1.05

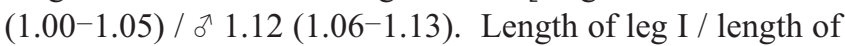
carapace 우 $2.19(2.12-2.30) /$ ð 2.20 (2.20-3.18). Femur III ventrally with a thick spine. Male palp (Figs. 12-13): in prolateral view, conductor apically swollen, median apophysis with long and sharp projection. Female genitalia (Fig. 12): epigyne with slim scape. Abdomen flattened, almost as long as wide or slightly longer than wide [length / width 우 $1.04(0.92-1.07)$ / 万 1.13 (1.04-1.54)].

Distribution. Thailand, China, and Japan.

\section{Acknowledgments}

We wish to express our thanks to Taksin Artchawakom, Director General of Sakaerat Environmental Research Station, and Wipada Vangsilabutr and Jirapat Bangtha for their help with our field work; and to Khunying Prapaisri Pitakpaivan, Advisor to the Permanent Secretary, Ministry of Agriculture and Cooperatives, for her much valued assistance in this work. We are also particularly grateful to Booppa Petcharad, Prince of Songkhla University, for providing the specimens used in this study, and to Peter Jäger and Julia Altmann, Senckenberg Museum, Frankfurt-am-Main, Germany, for loaning of invaluable specimens. This study was partly supported by a grant from the Agriculture Research and Development Agency (ARDA), Ministry of Agriculture and Cooperatives, Thailand.

\section{References}

Bayer, S. \& Schonhofer, A. L. 2013. Phylogenetic relationships of the spider family Psechridae inferred from molecular data, with comments on the Lycosoidea (Arachnida: Araneae). Invertebr. Syst., 27: 53-80.

Bösenberg, W. \& Strand, E. 1906. Japanische Spinnen. Abh. Senck. Naturf. Ges., 30: 93-422.

Chrysanthus, P. 1961. Die Gattung Anepsion Strand 1929 (Arach., Araneae: Araneidae-Araneinae). Senckenberg. Biol., 42: 463-477.

Chrysanthus, P. 1969. Additional remarks on the genus Anepsion Strand, 1929 (Araneae, Argyopidae). Zool. Meded. Leiden, 44: 3139.

Correa-Ramirez, M. M., Jiménez, M. L. \& León, F. J. G. D. 2010. Testing species boundaries in Pardosa sierra (Araneae: Lycosidae) using female morphology and COI mtDNA. J. Arachnol., 38: 538554.

Edgar, C. R. 2004. MUSCLE: multiple sequence alignment with high accuracy and high throughput. Nucleic Acids Res., 32: 17921797.

Folmer, O., Black, M., Hoew, W., Lutz, R. \& Vrijenhoek, R. 1994. DNA primers for ampliation of mitochondrial cytochrome oxidase subunit I from diverse metazoan invertebrates. Mol. Mar. Biol. Biotechnol., 3: 294-299.

Lattimore, V. L., Vink, C. J., Paterson, A. M., \& Cruickshank, R. H. 2011. Unidirectional introgression within the genus Dolomedes (Araneae: Pisauridae) in southern New Zealand. Invertebr. Syst., 25: 70-79.

Platnick, N. I. 2012. The world spider catalog, version 13.0. The American Museum of Natural History. Online at http://research.amnh.org/iz/spiders/catalog/ARANEIDAE. html (accessed 24. Oct. 2012)

Robinson, E. A., Blagoev, G. A., Hebert, D. N., \& Adamowicz, S. J. 2009. Prospects for using DNA barcoding to identify spiders in species-rich genera. In 'A Life Caught in a Spider's Web. Papers in Arachnology in Honour of Christo Deltshev'. (Eds P. Stoev, J. Dunlop and S. Lazarov.). Zookeys, 16: 27-46.

Simon, E. 1895. Histoire naturelle des araignées. Paris, 1: 761-1084. Song, D. X., Zhu, M. S. \& Chen, J. 1999. The Spiders of China. Hebei Sci. Technol. Publ. House, Shijiazhuang, 640 pp.

Strand, E. 1929. Zoological and palaeontological nomenclatorical notes. Act. Univ. Latviensis, 20: 1-29.

Tamura, K., Peterson, D., Peterson, N., Stecher, G., Nei, M., \& Kumar, S. 2011. MEGA5: Molecular Evolutionary Genetics Analysis using Maximum Likelihood, Evolutionary Distance, and Maximum Parsimony Methods. Mol. Biol. Evol., 28: 2731-2739.

Tanikawa, A. 2007. An identification guide to the Japanese spiders of the families Araneidae, Nephilidae and Tetragnathidae. Arachnol. Soc. Japan, 121 pp.

Tanikawa, A. 2009. Hersiliidae. Nephilidae, Tetragnathidae, Araneidae. Pp. 149, 403-463. In Ono, H. (ed.) The Spiders of Japan: with keys to the families and genera and illustrations of the 
species. Tokai Univ. Press, Kanagawa, xvi +738 pp.

Tanikawa, A. 2011. The first description of a male of Paraplectana tsushimensis (Araneae: Araneidae). Acta Arachnol., 60: 71-73.

Thorell, T. 1877. Studi sui Ragni Malesi e Papuani. I. Ragni di Selebes raccolti nel 1874 dal Dott. O. Beccari. Ann. Mus. Civ. Stor. Nat. Genova, 10: 341-637.

Vink, C. J., Fitzgerald, B. M., Sirvid, P. J. \& Dupérré, N. 2011. Reuniting males and females: redescriptions of Nuisiana arboris (Marples 1959) and Cambridgea reinga Forster \& Wilton 1973 (Araneae: Desidae, Stiphidiidae). Zootaxa, 2739: 41-50.

Yaginuma, T. 1962. Spiders from Osumi Peninsula, Mt. Takakuma and Mt. Kirishima, Kyushu, Japan. Misc. Rep. Res. Inst. Nat.
Resour. Tokyo, 56-57: 129-136.

Yaginuma, T. 1986. Spiders of Japan in Color (new ed.). Hoikusha Publ. Co., Osaka, xxiv + 305 pp.

Yin, C. M., Wang, J. F., Zhu, M. S., Xie, L. P., Peng, X. J. \& Bao, Y. H. 1997. Fauna Sinica: Arachnida: Araneae: Araneidae. Science Press, Beijing, xiii +460 pp.

Zhu, M. S., Song, D. X., Zhang, Y. Q. \& Wang, X. P. 1994. On some new species and new records of spiders of the family Araneidae from China. J. Hebei Norm. Univ. (Nat. Sci. Ed.), 1994(Suppl.): $25^{-52 .}$

Received March 28, 2013 / Accepted June 29, 2013

Appendix. Locality, haplotype and accession numbers of specimens used for molecular work. The unknown specimens were identified as Anepsion japonicum in this study.

\begin{tabular}{|c|c|c|c|c|}
\hline Species & locality & $\mathrm{N}$ & haplotype & Accession nos. \\
\hline Anepsion japonicum & Petchaburi Province & $20^{\Uparrow}$ & AJA01 & AB808475 \\
\hline unknown & Petchaburi Province & 2우 & AJA01 & AB808475 \\
\hline Anepsion japonicum & Chanthaburi Province & $10^{\lambda}$ & AJA01 & AB808475 \\
\hline unknown & Chanthaburi Province & 1 우 & AJA01 & AB808475 \\
\hline unknown & Songkhla Province & 1 우2juv. & AJA01 & AB808475 \\
\hline Anepsion japonicum & Chanthaburi Province & 2우 & AJA02 & AB808476 \\
\hline Anepsion depressum & Nakhon Ratchasima Province & 1 우 & ADE01 & AB808477 \\
\hline Anepsion depressum & Chanthaburi province & 1 우 & ADE02 & AB 808478 \\
\hline Anepsion depressum & Songkhla Province & 1 우 & ADE03 & AB808479 \\
\hline Anepsion depressum & Songkhla Province & 1 우 & ADE04 & AB 808480 \\
\hline
\end{tabular}

